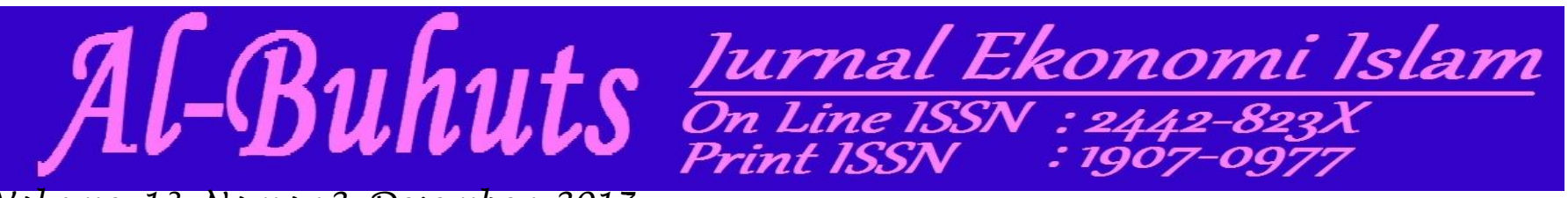

Volume. 13, Nomor 2, Desember 2017

\title{
Analisis Sistem Akuntansi Penerimaan Kas Pada Pelayanan Rawat Inap Rumah Sakit Umum Daerah Dunda Gorontalo
}

\author{
Mahfiza; \\ IAIN Sultan Amai Gorontalo \\ Mahfiza001@gmail.com
}

\begin{abstract}
Abstrak
Penelitian ini bertujuan untuk mengetahui lebih mendalam mengenai penerapan sistem akuntansi penerimaan kas pada rawat inap rumah sakit umum Dunda Kabupaten Gorontalo. Metode analisis yang digunakan adalah analisis dekriptif kualitatif dengan mengambil data sekunder pada bagian kasir dan piutang serta prosedur pelayanan rawat inap rumah sakit Dunda kabupaten Gorontalo mulai dari penerimaan pasien, pelayanan medis/penunjang medis, pelayanan perawatan, pelayanan obat hingga pelayanan adminstrasi keuangan.Hasil penelitian menunjukkan bahwa RSUD Dr.M.M Dunda Limboto mempunyai struktur organisasi yang tertulis sehingga telah jelas adanya garis wewenang dan tanggung jawab serta pembagian kerja fungsional. Setiap fungsi sudah dijalankan dengan cukup baik oleh masingmasing bagian, dokumen-dokumen yang digunakan pada sistem akuntansi penerimaan kas instalasi rawat inap pada RSUD Dr.M.M Dunda Limboto sudah memadai Setiap dokumen yang digunakan sudah terdapat otorisasi oleh pejabat yang berwenang. Pencatatan akuntansi telah menjamin bahwa semua transaksi yang terjadi dicatat sebagaimana mestinya dan didukung oleh dokumen pendukung yang telah diotorisasi oleh pihak yang berwenang. Prosedur yang dilaksanakan sudah sesuai dengan protap yang telah dibuat oleh RSUD Dr.M.M Dunda Limboto serta prosedur penatausahaan bendahara penerimaan yang tertera dalam Peraturan Bupati Tahun 2012 tentang organisasi dan tata kerja rumah sakit umum daerah Dr. M.M. Dunda Limboto Kabupaten Gorontalo.
\end{abstract}

\section{Kata Kunci : Sistem Akuntansi, Penerimaan Kas, Pelayanan}

\section{Pendahuluan}

Pelayanan rumah sakit diera sekarang tidak terlepas dari perkembangan ekonomi masyarakat. Hal ini tercermin pada perubahan fungsi klasik rumah sakit yang pada awalnya hanya memberi pelayanan yang bersifat penyembuhan saja terhadap pasien melalui rawat inap dan rawat jalan, bergeser ke pelayanan yang lebih komprehensif. Rumah sakit adalah suatu lembaga pelayanan kesehatan dan sekaligus sebagai suatu unit usaha (baik pemerintah maupun swasta), dimana lembaga kesehatan ini dari waktu ke waktu semakin lama akan semakin berkembang, baik dari segi kuantitas maupun dari 
segi kualitas dan dilihat dari berbagai macam bentuk rumah sakit kecil maupun besar yang ada di seluruh penjuru tanah air.

Sistem akuntansi penerimaan kas rumah sakit adalah Sistem Akuntansi Penerimaan kas yang baik tentunya sangat dibutuhkan oleh rumah sakit demi mencapai tujuannya, unsurunsur sistem akuntansi penerimaan kas yang baik adalah Proses aliran kas yang terjadi yang terdiri dari aliran kas masuk (cash flow) (Sudarmo,2006:61), Suatu catatan yang dibuat untuk melaksanakan kegiatan penerimaan uang dan penjualan tunai atau dari piutang yang siap dan bebas digunakan untuk kegiatan umum suatu entitas ,Mulyadi (2013:500)

Rumah Sakit merupakan suatu lembaga yang padat karya, padat modal dan teknologi maupun padat waktu. Disebut padat karya karena bergerak dibidang jasa yang melibatkan relatif banyak tenaga kerja, yaitu di bidang medis, paramedis perawatan, paramedis non perawatan dan tenaga non medis. Padat modal dan teknologi karena rumah sakit yang baik haruslah didukung dengan investasi yang besar untuk mencakup pengadaan fasilitas pelayanan seperti gedung, peralatan kedokteran yang canggih, obatobatan yang cukup dan memadai, tenaga dokter umum dan dokter ahli serta fasilitas penunjang lainnya seperti kendaraan, peralatan rumah sakit dan lain-lain. Sedangkan padat waktu dikarenakan rumah sakit dalam memberikan pelayanannya kepada masyarakat berlangsung selama 24 jam sehari dan tidak mengenal adanya hari libur (Arfan, $2010 ; 15)$.

Rumah sakit Umum Dunda Kabupaten Gorontalo, juga tidak terlepas dari aktivitas seperti rumah sakit pada umumnya. Rumah sakit ini memiliki beberapa fasilitas pelayanan kesehatan yang juga berfungsi sebagai sumber pendapatan. Salah satu pendapatan rumah sakit yang cukup besar adalah pendapatan dari pelayanan rawat inap dimana pelayanan rawat inap merupakan suatu pelayanan kesehatan bagi pasien yang dinyatakan oleh dokter untuk dirawat inap pada rumah sakit tersebut, agar pasien memperoleh perawatan yang optimal sehingga pasien sembuh.

Sumber utama penerimaan kas Rumah Sakit Umum Dunda Kabupaten Gorontalo. diperoleh dari instalasi rawat inap. Pada sistem penerimaan kas rawat inap, telah dibuat sistem untuk mengatur urut - urutan prosedur penerimaan kas rawat inap. Rumah sakit ini sebenarnya telah menggunakan sistem baru pada beberapa bagian yang berhubungan dengan penerimaan kas. Sistem baru yang digunakan berupa efisiensi pemakaian kode rekening untuk mengurangi kesalahan penjurnalan. Akan tetapi untuk bagian/divisi akuntansi masih 
menggunakan sistem lama yang dalam prosesnya masih menggunakan kode rekening lama yang sebenarnya sudah tidak diperlukan lagi. Selain itu, kartu debitur yang seharusnya dikirim ke bagian akuntansi secara harian, belum bisa berjalan lancar. Kartu debitur yang seharusnya hari ini dapat dijurnal, baru dikirim ke bagian akuntansi pada hari berikutnya, bahkan ada yang sampai dua sampai tiga hari berikutnya. Mengingat rumah sakit merupakan instansi yang penerimaan kas berlangsung setiap hari, kendala tersebut memungkinkan terjadinya kesalahan serta berpengaruh terhadap laporan kas harian. Karena pentingnya pendapatan kas dari rawat inap, maka rumah sakit ini memerlukan suatu sistem yang baik untuk mengelola penerimaan kas rawat inap. Dengan adanya sistem yang baik ini, dapat dihasilkan laporan kas harian yang tepat waktu.

Untuk menjalankan kegiatannya, rumah sakit Umum Dunda Kabupaten Gorontalo memerlukan suatu sistem akuntansi yang mendukungnya. Salah satu sistem yang dibutuhkan adalah sistem akuntansi penerimaan kas. Dengan sistem penerimaan kas yang baik, diharapkan uang yang masuk maupun keluar dapat terdeteksi dengan baik terutama pada kegiatan rawat inap rumah sakit tersebut. Dalam pelayanan rawat inap, sistem dan prosedur harus disusun sedemikian rupa sehingga terlihat langkah-langkah yang jelas dari segenap aktivitas mulai dari prosedur pendaftaran pasien, prosedur tindakan perawatan rawat inap sampai prosedur pasien pulang.

\section{Tinjauan Pustaka}

\subsection{Sistem Akuntansi Penerimaan Kas}

Sistem penerimaan kas menurut Bastian (2007:119) meliputi serangkaian proses, baik manual maupun terkomputerisasi, mulai dari pencatatan, penggolongan sampai peringkasan transaksi dan atau kejadian keuangan serta pelaporan keuangan dalam rangka mempertanggung- jawabkan anggaran yang berkaitan dengan penerimaan kas. Sistem penerimaan kas adalah satu prosedur yang yang dibentuk sesuai dengan urutan yang padu untuk kegiatan penerimaan kas yang terjadi secara rutin atau berulangkali sesuai dengan ketentuan perusahaan yang bersangkutan (Mulyadi, 2001:3).

Prosedur penerimaan kas melibatkan beberapa fungsi dalam perusahanaan agar transaksi penerimaan kas tidak berpusat pada satu bagian atau satu fungsi saja. Hal ini diperlukan agar menjamin terjadinya pengendalian intern yang baik. Baridwan (2009:157) menjelaskan bahwa fungsi yang terlibat dalam sistem penerimaan kas terdiri dari: 
a. Kasir

Kasir bertugas menerima uang yang berasal dari bagian surat masuk, pembayaran langsung atau dari penjualan. Setiap hari kasir membuat bukti setor ke bank dan menyetorkan semua uang yang diterimanya. Agar penerimaan uang ini dapat diawasi dengan baik maka satu lembar bukti setor dari bank langsung dikirimkan ke bagian akuntansi. Bukti setor yang diterima di bagian akuntansi dicocokkan dengan daftar penerimaan uang yang dibuat oleh bagian surat masuk dan oleh kasir. Salah satu cara pengawasan penerimaan uang langsung oleh kasir dapat dilakukan dengan dibuatnya bukti kas masuk yang diberi nomor urut yang dicetak.

b. Bagian Piutang.

Pada umumnya, fungsi bagian piutang dapat digolongkan menjadi tiga, yaitu :

- Membuat catatan piutang yang dapat menunjukkan jumlah-jumlah piutang kepada tiap-tiap langganan. Catatan ini disusun sedemikian rupa sehingga dapat diketahui sejarah kredit tiap-tiap langganan, jumlah maksimum kredit, dan keterangan-keterangan lain yang diperlukan. Karena bagian kredit bertugas menyetujui setiap penjualan kredit, maka catatan yang dibuat oleh bagian piutang ini akan menjadi dasar bagian kredit untuk mengambil keputusan. Oleh karena itu, catatan piutang harus dapat menunjukkan informasi-informasi yang diperlukan oleh bagian kredit

- Menyiapkan dan mengirimkan surat pernyataan piutang. Surat pernyataan piutang dapat dibuat dalam beberapa bentuk. Karena bentuknya bermacam-macam, dan tiap-tiap bentuk mempunyai hubungan yang erat dengan prosedur penyusunannya, maka perlu dipertimbangkan bentuk mana yang dipilih sesuai dengan metode jurnal dan posting, serta dengan kebutuhan informasinya

- Membuat daftar analisa umur piutang setiap periode. Daftar ini dapat digunakan untuk menilai keberhasilan kebijakan kredit yang dijalankan, dan juga sebagai dasar untuk membuat bukti memo yang mencatat kerugian piutang (Baridwan, 2009:145-146)

\subsection{Prosedur Rawat Inap Rumah Sakit}

Rawat Inap pada Rumah Sakit memiliki penjelasan dimana menurut Depkes, Pengertian Rawat Inap menurut Peraturan Depkes RI Tahun 2004, Rawat inap adalah pelayanan terhadap pasien masuk rumah sakit yang menempati tempat tidur perawatan untuk keperluan observasi, diagnosa, terapi, rehabilitasi medis atau pelayanan medis lainnya. 
Pelayanan rawat inap merupakan sumber utama pendapatan operasional pengendalian manajemen rumah sakit. Oleh karena itu semakin besar rumah sakit tersebut maka memerlukan pengelolahan sistem informasi akuntansi yang baik agar tidak terjadi kesalahan-kesalahan dalam pembebanan biaya perawatan yang akan mempengaruhi kepuasan pasien dan pada akhirnya membuat citra buruk rumah sakit tersebut dalam memberikan pelayanan kesehatan pada pasien. Kegiatan pelayanan rawat inap itu sendiri meliputi :
a. penerimaan pasien
b. pelayanan medis/ penunjang medis.
c. pelayanan perawatan,
d. pelayanan obat,
e. pelayanan administrasi keuangan

Model proses manual adalah bentuk yang paling tua dan tradisional dari sistem akuntansi. Sistem manual ini membentuk peristiwa-peristiwa fisik, sumber daya dan personal yang mencirikan kebanyakan proses bisnis. Dalam hal ini termasuk tugas-tugas seperti pengambilan pesanan, penyimpanan bahan baku. Pendekatan flat file seringkali berkaitan dengan sistem yang disebut sebagai sistem warisan (legacy systems). Sistem ini merupakan sistem kerangka utama dalam sistem mainframe besar yang diterapkan pada akhir tahun 1960 sampai 1980-an

Terdapat tiga tujuan pokok dari perancangan sistem akuntansi untuk rumah sakit menurut manual sistem akuntansi dan prosedur keuangan untuk rumah sakit, dalam buku manajemen operasional rumah sakit, Steinbart (2004:10), yaitu

a. Untuk membantu kelancaran pelaksanaan kegiatan operasional rumah sakit. Misalnya kegiatan pelayanan untuk pasien rawat jalan dan pelayanan untuk pasien rawat inap.

b. Untuk melaksanakan proses dan menghasilkan laporan akuntansi yang ditujukan untuk kepentingan pihak luar atau pertanggungjawaban pimpinan rumah sakit terhadap pihak luar (pihak ekstern).

c. Untuk melaksanakan proses dan menghasilkan laporan akuntansi untuk kepentingan berbagai pimpinan dalam rumah sakit dalam menjalankan fungsi-fungsi manajerialnya.

Sistem informasi akuntansi yang ada pada rumah sakit harus dapat mengidentifikasikan keadaan pasien-pasien sebelum diberikan pelayanan kesehatan. Informasi yang diperlukan dari pasien tergantung dari rumah sakit yang bersangkutan dan peraturan lainnya yang berlaku. Informasi awal yang dibutuhkan oleh rumah sakit adalah :

a. Nama pasien, alamat tempat tinggal dan identitas lainnya yang berhubungan dengan pasien.

b. Umur, jenis kelamin dan tempat tanggal lahir. 
c. Pekerjaan

d. Informasi penanggung jawab, kepada siapa biaya perawatan pasien ditagih

e. Nama dan alamat keluarga, sahabat dekat atau alamat lain yang dapat dihubungi bila pasien dalam keadaan gawat.

Informasi awal tersebut diperlukan oleh rumah sakit dengan tujuan sebagai berikut :

a. Memudahkan mengetahui kepada siapa jasa akan diberikan.

b. Memudahkan untuk menghubungi keluarga pasien, sahabat atau teman dekat apabila terjadi sesuatu yang gawat dan memerlukan tindakan segera yang perlu persetujuan dari keluarga pasien.

c. Memudahkan penagihan biaya perawatan pasien, kepada siapa tagihan tersebut dapat diberikan untuk dibayar.

d. Memudahkan untuk mengumpulkan informasi lainnya yang berhubungan dengan pasien yang mungkin berguna untuk kepentingan rumah sakit pada umumnya atau untuk keperluan penyelidikan ilmu kedokteran

Pada umumnya prosedur dasar rumah sakit yang pertama adalah prosedur pendaftaran pasien, kedua adalah prosedur ruangan perawatan dan pelayanan medis serta penunjang medis yang merupakan pemberian pelayanan dengan menggunakan segala sumber daya dan prosedur yang terakhir adalah prosedur penyiapan dan penagihan piutang sebagai akibat kegiatan perawatan pasien karena pelayanan tersebut telah diberikan atau tidak diperlukan lagi.

Bagian-bagian yang terlibat dalam pencatatan transaksi jasa pelayanan kesehatan di rumah sakit dalam menyusun sejumlah prosedur-prosedurnya, yaitu :

a. Bagian penerimaan pasien, yaitu suatu tempat penerimaan pasien yang mencatat data pasien seperti yang tersebut diatas.

b. Bagian rekam medis, yaitu bagian yang mengawasi ketertiban pembuatan catatan-catatan medis seluruh rumah sakit sesuai dengan ketentuan termasuk catatan-catatan pelayanan penerimaan pasien agar sesuai dengan sistem pencatatan yang telah ditentukan.

c. Bagian akuntansi, yaitu bagian yang memproses semua laporan yang masuk dari bagianbagian di rumah sakit sehingga menjadi laporan keuangan yang diperlukan oleh pihak manajemen rumah sakit maupun pihak luar rumah sakit yang berkepentingan.

Bagian keuangan, yaitu bagian yang menangani penerimaan dan pengeluaran uang dalam rumah sakit, juga menangani masalah piutang rumah sakit sehingga rumah sakit tidak mengalami kerugian karena bertumpuknya piutang jasa pelayanan yang diberikan rumah sakit kepada pasien jaminan. Bagian-bagian tersebut sangat erat kaitannya satu sama lain dan sangat penting peranannya didalam menghasilkan informasi yang dibutuhkan oleh pihak intern dan ekstern rumah sakit. 


\section{Hasil dan Pembahasan}

Sistim akuntansi penerimaan kas dan hal-hal yang berkaitan dengan sistem pada Rumah Sakit Umum Daerah Dr.M.M Dunda Limboto adalah :

\section{1. Fungsi yang Terkait}

a. Fungsi Pendaftaran Pasien

Fungsi ini bertanggung jawab mendaftar pasien yang akan masuk rawat inap. Pasien rawat inap mendapatkan Dokumen Rekam medik (Dok RM) yang berisi surat pernyataan, surat perawatan, dan lembar pelayanan. Fungsi ini dilaksanakan oleh bagian perawat yang saat itu bertugas di Instalasi Gawat Darurat (IGD) Rumah Sakit Umum Daerah Dr.M.M Dunda Limboto .

b. Fungsi Pelayanan Medis

Fungsi pelayanan medis bertanggung jawab memberikan pelayanan medis kepada pasien. Fungsi ini dilakukan oleh bagian rekam medis dan bagian keperawatan.

c Fungsi Penunjang Medis

Fungsi penunjang medis bertanggung jawab memberikan pelayanan penunjang medis kepada pasien. Fungsi ini dilakukan oleh bagian laboratorium dan bagian apotek.

c. Fungsi Pencatatan dan Pelaporan.

Fungsi pencatatan dan pelaporan bertanggungjawab menghitung, mencatat dan melaporkan hasil penerimaan kas. Fungsi ini dilakukan oleh bagian kasir, bendahara penerimaan kas, dan pembantu bendahara penerimaan kas.

e. Fungsi penerimaan dan penyimpanan kas

Fungsi penerimaan dan penyimpanan kas bertanggung jawab menerima dan menyimpan uang dari hasil jasa perawatan kesehatan yang telah diberikan.

f. Fungsi Akuntansi

Fungsi ini bertanggung jawab mencatat dan menghitung penerimaan kas ke dalam jurnal penerimaan kas serta membuat dan melaporkan laporan keuangan. Fungsi ini dilaksanakan oleh bagian akuntansi.

g. Fungsi penagihan

Fungsi ini bertanggung jawab dalam penerimaan kas dengan cara piutang atau diangsur kemudian mencatatnya dalam buku piutang. 


\section{Dokumen yang Digunakan :}

a. Rekam Medik (RM)

Catatan atas tindakan yang dilakukan oleh tenaga medis berisi tentang jasa pelayanan yang diberikan.

b. Bukti Pembayaran (BP)

Pembuatan bukti pembayaran setelah ada persetujuan dari dokter bahwa pasien diperbolehkan pulang. Bukti ini terdiri dari 2 lembar, lembar pertama untuk pasien lembar ke dua untuk bagian kebendaharaan atau keuangan.

c. Rincian Biaya Rawat Inap

Formulir ini dibuat oleh bagian administrasi yang berisi tentang biaya yang atas fasilitas yang diberikan baik medis maupun non medis.

d. Surat Tanda Setor (STS)

Merupakan bukti setor pembayaran pasien yang dibuat oleh bagian kasir atau administrasi ruang inap. Bukti ini dibuat hanya selembar untuk dilaporkan ke bagian keuangan atau kebendaharaan.

\subsection{Catatan Akuntansi yang Digunakan}

Catatan akuntansi yang digunakan dalam sistem penerimaan kas dari pasien rawat inap RSUD Dunda Limboto adalah sebagai berikut :

a. Register Pembayaran Rawat Inap

Register ini digunakan untuk mencatat semua penerimaan kas yang berasal dari instalasi rawat inap.

b. Laporan Harian

Laporan harian mencatat jumlah penerimaan kas selama sehari pada instalasi rawat inap dan pengeluaran lainnya.

c. Buku Besar

Buku besar dibuat untuk menggolongkan dan memisahkan penerimaan kas berdasarkan pos-posnya.

d. Laporan Realisasi Pendapatan dan Penyetoran Uang

Laporan realisasi pendapatan dan penyetoran uang merupakan catatan yang dibuat sebagai lampiran pertanggung jawaban.

e. Jurnal Penarimaan Kas 
Jurnal penerimaan kas digunakan untuk mencatat semua penerimaan kas baik yang berasal dari instalasi rawat inap, instalasi rawat jalan dan penerimaan kas lainnya.

f. Jurnal Umum Lainnya

Jurnal umum digunakan untuk mencatat transaksi selain penerimaan kas dan pengeluaran di RSUD Dr.M.M Dunda Kabupaten Gorontalo.

\section{Dokumen yang digunakan}

Dokumen yang digunakan dalam penerimaan kas dari pasien rawat inap di RSUD Dr.M.M Dunda Limboto adalah sebagai berikut:

a. Surat Perintah Rawat Inap

Dokumen ini berisi perintah dari dokter kepada pasien agar menjalani rawat inap.

b. Lembar Masuk Darurat

Lembar ini berisi keterangan bahwa pasien melakukan pemeriksaan melalui Instalasi Gawat Darurat (IGD).

c. Kartu Diagnosa

Kartu diagnosa merupakan catatan hasil diagnosa penyakit pasien. Kartu ini diisi oleh dokter baik di instalasi rawat jalan, instalasi rawat inap, maupun IGD.

d. Berkas Rekam Medis (RM)

Berkas rekam medis merupakan kumpulan data yang merekam pelayanan yang telah diberikan oleh rumah sakit selama pasien menjalani rawat inap. Berkas rekam medis terdiri dari ringkasan riwayat masuk dan keluar, anamnase, perjalanan penyakit, lembaran penempelan hasil penunjang, ringkasan keluar, penempelan koresponden, penempelan resep, pengkajian perawatan, catatan asuhan keperawatan, ringkasan pasien pulang.

e. Kartu Identitas Pasien Rawat Inap

Kartu ini berisi data identitas pasien, tanggal masuk, no. register masuk, nama bangsal, dan tanggal, keluar. Kartu ini digunakan untuk mempermudah petugas keperawatan atau rekam medis untuk mencari berkas pasien.

f. Surat Perawatan 
Lembar ini berisi data identitas pasien dan keluarga pasien yang dirawat inap. Surat perawatan ini ditandatangani oleh pasien atau keluarga pasien.

g. Surat Pernyataan Dirawat

Lembar ini berisi pernyataan pasien/ keluarga pasien bahwa pasien menyetujui untuk menjalani rawat inap di RSUD Dr.M.M Dunda Kabupaten Gorontalo.Dokumen ini diserahkan kepada pasien.

h. Surat Pengantar Laboratorium

Dokumen ini diisi oleh dokter sebagai perintah kepada pasien untuk menjalani pemeriksaan di laboratorium.

i. Lembar Hasil Laboratorium

Dokumen ini berisi hasil pemeriksaan di laboratorium.

j. Buku Hasil Laboratorium

Dokumen ini berisi hasil laboratorium seluruh pasien.

k. Lembar Biaya Laboratorium

Dokumen ini berjumlah rangkap 2 digunakan untuk menuliskan biaya pemeriksaan di laboratorium.

1. Resep

Lembar ini diisi oleh dokter untuk membeli obat yang diperlukan.

m.Bukti Penerimaan Uang Biaya Obat

Bukti penerimaan uang biaya obat terdiri dari 2 rangkap bernomor urut tercetak. Bukti ini digunakan sebagai kuitansi pembayaran obat.

n. Rincian Pelayanan Rawat Inap

Dokumen ini berisi rincian pelayanan yang telah diberikan kepada pasien meliputi visite dokter, tindakan non medis, O2, dan lain-lain. Dokumen ini digunakan sebagai dasar bagi bagian kasir untuk merinci seluruh biaya pelayanan rawat inap.

o. Catatan Pelayanan Tindakan Perawat Rawat Inap (CPTPRI)

Dokumen ini berisi catatan pelayanan tindakan yang diisi oleh bagian keperawatan. Catatan pelayanan tindakan meliputi lima golongan jenis tindakan yaitu tindakan kecil, sedang, besar, khusus, dan elektromedik. Dokumen ini digunakan sebagai dasar bagi bagian kasir untuk merinci seluruh biaya rawat inap.

p. Perincian Biaya Pelayanan Kesehatan Pasien Rawat Inap 
Dokumen ini digunakan untuk merinci seluruh biaya atas jasa pelayanan yang diberikan oleh rumah sakit yang terdiri dari 3 rangkap. Perincian jasa dibagi menjadi tiga golongan, yaitu: jasa sarana, jasa pelayanan, bahan alat habis pakai. Setiap jasa yang diberikan dihitung berdasarkan tarif yang sesuai dengan peraturan daerah yang berlaku. Seluruh total biaya kemudian ditagihkan kepada pasien.

q. Bukti Penerimaan Uang Biaya Rawat Inap

Bukti penerimaan uang terdiri dari 2 lembar bernomor urut tercetak, digunakan sebagai kuitansi penerimaan uang dari pasien yang sudah tidak lagi dirawat inap dan digunakan sebagai dasar pencatatan penerimaan kas.

r. Bukti Penyerahan Uang dan Bukti Setor Pajak

Bukti penyerahan uang dan bukti setor pajak merupakan bukti penyerahan uang yang diterima oleh serta penyetoran retribusi kepada kas daerah, selanjutnya digunakan untuk pertanggungjawaban kepada Pemda Kabupaten Gorontalo. Dokumen ini terdiri 4 rangkap.

s. Surat Tanda Setoran

Dokumen ini terdiri dari 4 rangkap digunakan untuk menyetor pengutan daerah berupa retribusi hasil pelayanan kesehatan RSUD Dr.M.M Dunda Kabupaten Gorontalo.

Catatan akuntansi yang digunakan dalam sistem penerimaan kas instalasi rawat inap pada RSUD Dr.M.M Dunda Kabupaten Gorontalo adalah sebagai berikut:

a. Rekapitulasi Rawat Inap

Rekapitulasi rawat inap digunakan untuk mencatat semua penerimaan kas dari rawat inap. Perhitungannya dilakukan setiap hari berdasarkan bukti penerimaan uang biaya rawat inap dan rincian biaya rawat inap, kemudian rekapitulasi ini diserahkan kepada bendahara penerimaan kas.

b. Rekapitulasi Penerimaan Harian

Rekapitulasi penerimaan harian merupakan daftar rekap yang berisi seluruh biayabiaya pelayanan yang ditanggung oleh seluruh pasien, seperti rawat inap, rawat jalan, farmasi, laboratorium, radiologi, kamar operasi, IGD, jasa konsultasi gizi, ambulance, dan lain-lain. Selanjutnya rekapitulasi ini dipergunakan bendahara penerimaan kas untuk membuat laporan harian.

c. Laporan Harian 
Laporan harian mencatat total penerimaan kas selama satu hari yang pencatatannya berdasarkan rekapitulasi penerimaan harian. laporan harian ini digunakan sebagai lampiran pertanggungjawaban penerimaan kas daerah kepada Pemda Kabupaten Gorontalo. Dokumen ini dicetak sebanyak 4 rangkap.

d. Buku Kas Umum

Buku kas umum digunakan untuk mencatat mengenai semua penerimaan dan pengeluaran kas. Penerimaan kas berasal dari rawat jalan, rawat inap, IGD, farmasi,dll. Setiap penerimaan harian harus disetorkan ke Bank dan dicatat dalam pengeluaran kas.

\subsection{Jaringan Prosedur Penerimaan Kas yang Membentuk Sistem.}

a. Prosedur Pendaftaran Pasien Rawat Inap

1) Setelah pasien periksa di instalasi rawat jalan atau instalasi gawat darurat, oleh dokter instalasi rawat jalan dan instalasi gawat darurat diharuskan untuk rawat inap, maka petugas mengantar ke tempat pendaftaran pasien.

2) Petugas pendaftaran menyiapkan dokumen-dokumen meliputi surat perintah dirawat dari dokter, kartu diagnosa yang telah diisi oleh dokter dan lembar masuk darurat apabila melalui Instalasi Gawat Darurat (IGD) dan menyiapkan dokumen pemeriksaan / berkas rekam medis yang diperlukan, meliputi ringkasan riwayat masuk dan keluar, anamnase, perjalanan penyakit, lembaran penempelan hasil penunjang, ringkasan keluar, penempelan koresponden, penempelan resep, pengkajian perawatan, catatan asuhan keperawatan, ringkasan pasien pulang.

3) Petugas pendaftaran mencatat identitas pasien pada lembar RM 1 (lembar ringkasan masuk dan keluar), kartu identitas pasien rawat inap, surat perawatan, surat pernyataan serta memesan kamar yang dikehendaki pasien.

4) Setelah selesai didaftar, petugas mengantarkan berkas rekam medis ke bangsal.

b. Prosedur Penerimaan Pasien Rawat Inap

1) Perawat memeriksa kelengkapan dokumen dan berkas rekam medis dan menyiapkan kamar pasien.

2) Perawat melakukan anamnase pasien dengan mendata keluhan utama riwayat penyakit dan perawatannya, serta melakukan fisik diagnostik rutin, tekanan darah, suhu, nadi dan pernafasan. 
3) Mencatat hasil anamnase dan pemeriksaan fisik pada berkas rekam medis, lembar catatan tindakan perawat rawat inap dan lembar rincian pelayanan rawat inap.

4) Setiap pencatatan pada berkas rekam medis ditandatangani oleh petugas yang berwenang yaitu dokter, kepala bangsal, dan perawat jaga bangsal.

5) Setiap pencatatan pada catatan tindakan pelayanan perawat rawat inap dan rincian pelayanan rawat inap ditandatangani oleh perawat jaga bangsal.

6) Dokter datang, dan melaksanakan pemeriksaan. Hasil pemeriksaan dicatat pada kartu diagnosa dan membubuhkan tanda tangan.

7) Setelah melaksanakan pemeriksaan, kemudian dokter membuat resep obat yang telah ditandatangani berjumlah rangkap 3. Blangko resep ditulis nama, umur, ruang rawat, alamat, kemudian diserahkan kepada perawat.

8) Oleh perawat, blangko resep lembar 1 dan 2 diserahkan kepada keluarga pasien untuk ditebus di apotek. Lembar 3 diarsip.

9) Apabila dokter memerintahkan agar pasien menjalani pemeriksaan laboratorium, maka pasien dibuatkan surat pengantar yang telah diotorisasi oleh dokter dan diserahkan ke bagian laboratorium.

c. Prosedur Pemeriksaan di Laboratorium.

1) Bagian laboratorium menerima surat pengantar laboratorium.

2) Petugas laboratorium mengambil sampel darah ke bangsal.

3) Sampel darah dibawa ke laboratorium dan diperiksa sesuai permintaan.

4) Hasil dikontrol kembali, apa sudah sesuai permintaan dan dicatat pada buku dan membuat hasil laboratorium dengan blangko yang ada di laboratorium, kemudian diserahkan kepada petugas bangsal untuk diserahkan kepada dokter.

5) Petugas laboratorium mencatat biaya pada lembar biaya pemeriksaan laboratorium rangkap 2 dan membubuhkan tanda tangan . Lembar 1 diserahkan kepada petugas bangsal untuk disatukan dengan berkas rekam medis, sedangkan lembar 2 diarsip sementara.

d. Prosedur Obat Pasien Rawat Inap

1) Bagian apotek menerima resep rangkap 2 dari pasien

2) Perawat menyerahkan resep kepada pasien/keluarga dan diberitahu untuk membeli resep tersebut ke apotek rumah sakit (pada instalasi farmasi B).

3) Tembusan blanglo resep lembar 1 untuk pasien, sedangkan lembar 2 diarsip 
4) Petugas membuat bukti penerimaan uang biaya obat rangkap 2 dan membubuhkan tanda tangan . Lembar 1 diserahkan kepada pasien dan lembar ke 2 diarsip sementara.

e. Prosedur Penghitungan Biaya Perawatan Bagi Pasien Pulang Di Kasir.

1) Petugas bangsal mengirimkan rincian pelayanan rawat inap, catatan tindakan pelayanan rawat inap, dan lembar biaya pemeriksaan laboratorium ke bagian kasir.

2) Bagian kasir membuat rincian biaya sesuai dengan tarif yang telah ditentukan.

3) Rincian biaya rawat inap dicetak sebanyak 3 rangkap. Lembar 1 diserahkan kepada pasien, lembar 2 diserahkan kepada petugas bangsal sebagai tanda bahwa pasien telah membayar, lembar 3 diarsip. Setelah membuat rincian biaya rawat inap, kemudian bagian kasir membuat tanda bukti penerimaan uang biaya rawat inap rangkap 2 .

4) Bagian kasir menyerahkan rincian biaya rawat inap lembar 1 beserta tanda bukti penerimaan uang biaya rawat inap 2 lembar kepada pasien.

5) Kemudian pasien melakukan pembayaran di Bank..

f. Prosedur Pembayaran di Bank.

1. Pasien membayarkan seluruh biaya ke Bank dengan membawa bukti penerimaan uang.

2. Petugas bank memberikan cap lunas dalam bukti penerimaan uang biaya rawat inap, kemudian lembar 1 diserahkan kepada pasien/ keluarga pasien. Lembar 2 diserahkan kepada pembantu bendahara penerimaan kas.

g. Prosedur pencatatan penerimaan kas.

1) Pembantu bendahara penerimaan kas menerima bukti penerimaan uang dan bukti setor bank dari Bank, kemudian membuat rekapitulasi rawat inap.

2) Pembantu bendahara penerimaan kas membuat rekapitulasi penerimaan harian dari seluruh penerimaan kas baik dari rawat jalan, rawat inap, farmasi, laboratorium, radiologi, kamar operasi, IGD, jasa konsultasi gizi, ambulance, dan penerimaan kas lainnya direkap menjadi satu.

3) Rekapitulasi penerimaan harian diserahkan kepada bendahara penerimaan kas untuk dibuat laporan harian, Surat Tanda Setoran, Bukti Penyerahan Uang dan Bukti Setor Retribusi 
Volume. 13, Nomor 2, Desember 2017

Halaman. 39-56
Analisis Sistem Akuntansi

Penerimaan Kas Pada Pelayanan

Rawat Inap Rumah Sakit Umum

Daerah Dunda Gorontalo

4) Laporan tersebut diotorisasi oleh bendahara penerimaan dan direktur, kemudian dilaporkan kepada PPKD selaku BUD.

5) Bendahara penerimaan kas melakukan pencatatan dalam Buku Kas Umum yang isinya menginformasikan total semua penerimaan kas bank yang berasal dari instalasi rawat inap, instalasi gawat darurat, instalasi rawat jalan, farmasi, laboratorium, radiologi, kamar operasi, IGD, jasa konsultasi gizi, ambulance dan sumber penerimaan kas lainnya juga pengeluaran kas yang dikirim ke bendahara umum daerah (BUD) pada saat dilakukan laporan pertanggungjawaban pihak Rumah Sakit Umum Daerah kepada Pemda melalui Bendahara Umum Daerah. Buku Kas Umum ini dilaporkan setiap bulan dan diotorisasi oleh bendahara penerimaan dan direktur.

6). Bagan Alir yang Terkait Sistem Penerimaan Kas

Berikut adalah gambar bagan alir prosedur yang berkaitan dengan penerimaan kas yang berasal dari instalasi rawat inap RSUD

\section{Gambar 4.7 Flow Chart Bagian Kasir dan Bendahara Penerimaan}
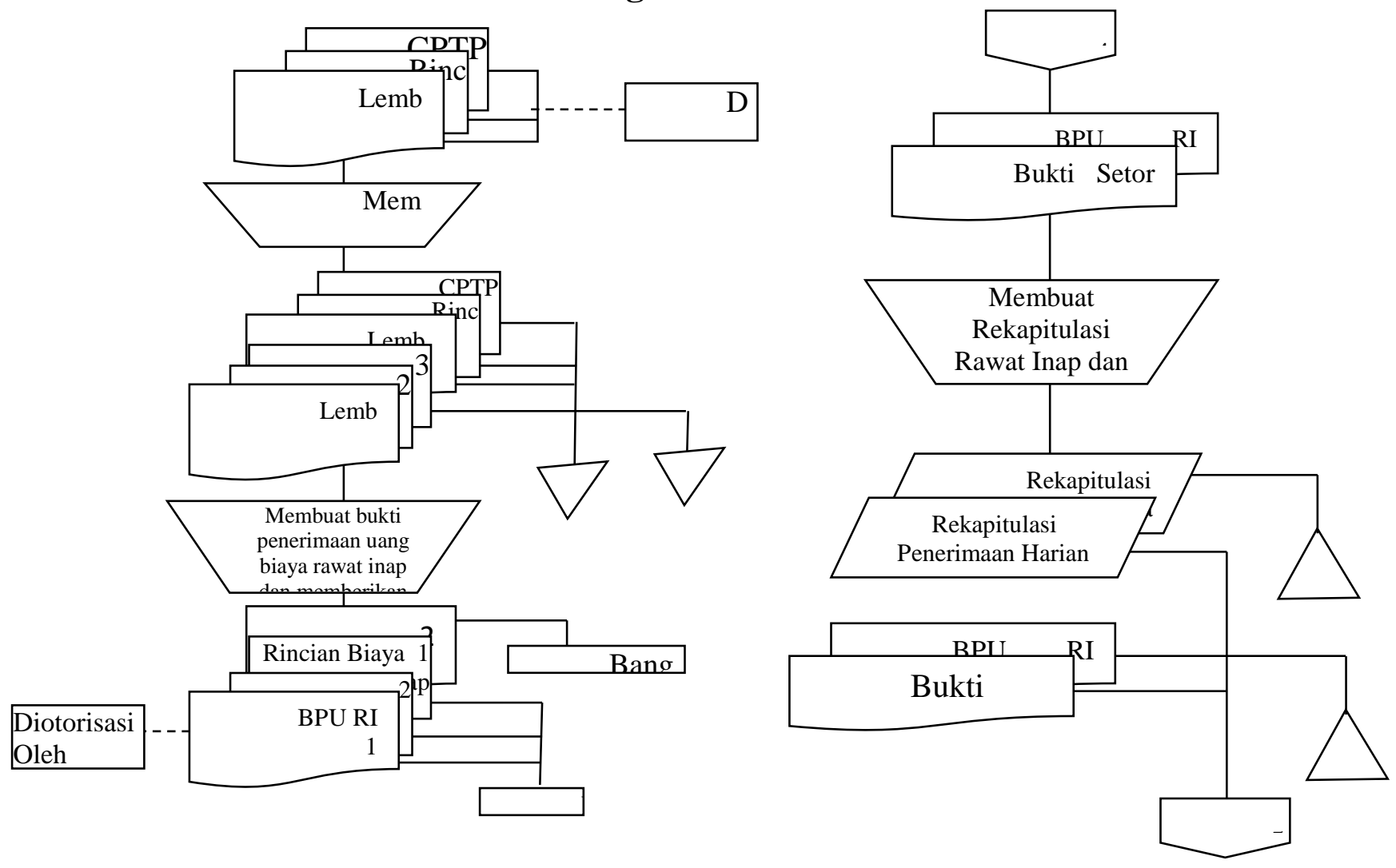

Sumber : Bagan Alir Dokumen Sistem Penerimaan Kas Instalasi Rawat Inap pada Rumah Sakit Umum Daerah Dr.M.M Dunda Limboto 
Volume. 13, Nomor 2, Desember 2017

Halaman. 39-56
Analisis Sistem Akuntansi

Penerimaan Kas Pada Pelayanan

Rawat Inap Rumah Sakit Umum

Daerah Dunda Gorontalo

\subsection{Evaluasi Terhadap Fungsi yang Terkait}

\section{a. Evaluasi Terhadap Dokumen yang Digunakan}

Dokumen-dokumen yang digunakan pada sistem akuntansi penerimaan kas instalasi rawat inap pada RSUD Dr.M.M Dunda Limboto sudah memadai. Setiap dokumen yang digunakan sudah terdapat otorisasi oleh pejabat yang berwenang, misalnya dokumen CPTPRI dan rincian pelayanan rawat inap yang diotorisasi oleh kepala bangsal. Selain itu dokumen yang digunakanuntuk melaporkan ke BUD seperti surat tanda setoran, bukti penyerahan uang dan bukti setor pajak sudah sesuai dengan peraturan yang ditetapkan dan diotorisasi oleh direktur dan bendahara penerimaan. Bukti penerimaan uang sebagai dokumen pendukung sudah bernomor urut tercetak, tetapi jumlah rangkap hanya 2. Lembar 1 diserahkan kepada pasien sebagai tanda bukti telah membayar. Lembar 2 digunakan untuk arsip pembantu bendahara penerimaan, sehingga pada bagian Bank tidak memiliki arsip bukti penerimaan uang.

\section{b. Evaluasi Terhadap Catatan Akuntansi.}

Bagian pencatatan penerimaan kas pada RSUD Dr.M.M Dunda Limboto menggunakan catatan akuntansi yaitu rekapitulasi rawat inap, rekapitulasi penerimaan harian, laporan harian, buku kas umum. Pencatatan ke dalam catatan akuntansi tersebut sudah berdasarkan atas dokumen pendukung yang telah diotorisasi oleh pejabat yang berwenang. Misalnya rekapitulasi rawat inap yang dibuat oleh pembantu bendahara penerimaan kas harus berdasarkan bukti penerimaan uang biaya rawat inap yang sudah ditandatangani oleh bagian kasir dan sudah di cap lunas oleh Bank. Setiap pencatatan ke dalam catatan akuntansi dilakukan oleh karyawan yang diberi wewenang, sehingga tanggungjawab atas pengubahan catatan akuntansi dapat dibebankan kepada karyawan tersebut.

\section{c. Evaluasi Terhadap Prosedur}

Prosedur yang dilaksanakan pada sistem penerimaan kas instalasi rawat inap pada RSUD Dr.M.M Dunda Limboto sudah cukup memadai. Prosedur yang dilaksanakan tidak hanya melibatkan satu bagian dalam satu jaringan prosedur. Hal ini berarti telah terdapat pemisahan fungsi yang jelas sehingga masing-masing bagian dan struktur organisasi mempunyai tanggungjawab yang jelas dalam menyusun dan melaksanakan sistem akuntansi penerimaan kas instalasi rawat inap pada RSUD Dr.M.M Dunda Limboto. Prosedur yang dilaksanakan sudah sesuai dengan protap yang dibuat oleh RSUD Dr.M.M Dunda Limboto dan prosedur penatausahaan bendahara penerimaan yang tertera pada Peraturan Bupati Gorontalo. Keseluruhan prosedur yang membentuk sistem telah dapat memberikan pelayanan yang memadai kepada pasien. 
Setiap kegiatan yang terjadi diotorisasi oleh pejabat yang berwenang. Adanya pencocokkan saldo uang kas yang dicatat dengan saldo kas yang diterima oleh Bank secara harian. Hal ini juga dilakukan untuk memperkecil resiko kehilangan kas dan mempermudah pengecekan apabila terjadi kesalahan pencatatan kas.

Hasil analisis dan penelitian ini sejalan dengan hasil penelitian sebelumnya yang dilakukan oleh Febrianita yang juga menyimpulkan bahwa sistem penerimaan kas rawat inap bangsal umum pasien kelas I RS. Kasih Ibu surakarta sudah baik, hal ini dibuktikan oleh adanya pemisahan fungsi antara fungsi operasi, fungsi pencatatan dan fungsi penyimpanan.

Prosedur penerimaan kas instalasi rawat inap masih terdapat kekurangan yaitu penerimaan kas yang diterima oleh Bank hanya sampai jam 11 saja. Setelah jam tersebut, penerimaan kas diterima oleh bagian kasir dan disetorkan ke Bank keesokan harinya. Hal tersebut dapat menyebabkan penyalahgunaan kas oleh petugas penerima kas

\section{Kesimpulan dan Saran}

Berdasarkan hasil analisis dan pembahasan pada bab sebelumnya maka dapat ditarik kesimpulan sebagai berikut :

1. Sistem akuntansi penerimaan kas instalasi rawat inap pada RSUD Dr.M.M Dunda Limboto sudah memadai dan sesuai dengan sistem akuntansi yang baik. Sudah terdapat pemisahan fungsi yang jelas antara fungsi operasional, fungsi penerimaan kas dan penyimpanan kas serta fungsi pencatatan dan pelaporan.

2. Pencatatan akuntansi telah menjamin bahwa semua transaksi yang terjadi dicatat sebagaimana mestinya dan didukung oleh dokumen pendukung yang telah diotorisasi oleh pihak yang berwenang. Prosedur yang dilaksanakan sudah sesuai dengan protap yang telah dibuat oleh RSUD Dr.M.M Dunda Limboto serta prosedur penatausahaan bendahara penerimaan yang tertera dalam Peraturan Bupati Tahun 2012 Tentang Organisasi Dan Tata Kerja Rumah Sakit Umum Daerah Dr. M.M. Dunda Limboto Kabupaten Gorontalo

Berdasarkan Analisis dan kesimpulan hasil penelitian di atas, penulis memberikan saran dan masukan :

1. Bagi RSUD Dr.M.M Dunda Limboto khususnya bagian kasir Sebaiknya antara kasir dengan bagian pendaftaran itu terpisah agar para pegawai dapat bekerja lebih efektif dan efisien dan pemisahan fungsi antara yang satu dengan yang lainnya agar lebih ditekankan supaya para pegawai lebih mengerti akan tugasnya masing-masing. 
Volume. 13, Nomor 2, Desember 2017

Halaman. 39-56
Analisis Sistem Akuntansi

Penerimaan Kas Pada Pelayanan

Rawat Inap Rumah Sakit Umum

Daerah Dunda Gorontalo

2. Bagi peneliti selanjutnya disarankan melakukan penelitian yang leih luas dan secara menyeluruh khususnya yang berkaitan dengan pencatatan akuntasi, audit dan laporan dan perpajakan.

\section{Daftar Pustaka}

Baridwan, Zaki. 2009. Sistem Akuntansi Penyusunan Prosedur dan Metode.Edisi Kelima. Yogyakarta: BPFE-Yogyakarta.

Bastian, Indra, dan Gatot Soepriyanto. 2003. Sistem Akuntansi Sektor Publik: Konsep untuk Pemerintah Daerah. Jakarta: Salemba Empat.

Bodnar, George H., dan William S. Hopwood. 2003.Sistem Informasi Akuntansi. Buku Satu. Edisi Kedelapan. Jakarta: PT.Indeks.

2004. Sistem Informasi Akuntansi. Buku Dua. Edisi Kedelapan. Jakarta: PT PT.Indeks.

Chaerunnisa 2011, Sistem Akuntansi Penerimaan Kas pada Rawat Inap Rumah Sakit ATTurots Al-Islami Laporan magang, Jakarta

Hall, James A. 2011. Accounting Information Systems: Sistem Informasi Akuntansi. Buku Satu. Edisi Empat. Jakarta: Salemba Empat.

Ikhsan,Arfan.2010. Akuntansi dan Manajemen Keuangan Rumah Sakit. Medan. Graha Ilmu

Jusup, Al. Haryono. 2005.Dasar-Dasar Akuntansi. Edisi Enam. Yogyakarta: Bagian Penerbitan Sekolah Tinggi Ilmu Ekonomi YKPN.

Krismiaji. 2002.Sistem Informasi Akuntansi . Yogyakarta: UPP AMP YKPN.

Mardi. 2011.Sistem Informasi Akuntansi.Bogor: Penerbit Ghalia Indonesia.

Mulyadi. 2011. Auditing. Buku Satu. Edisi Enam. Jakarta: Salemba Empat.

Puspitawati, Lilis, dan Sri Dewi Anggadini. 2011. Sistem Informasi Akuntansi. Yogyakarta: Graha Ilmu.

Rahma Amida, 2010, Evaluasi Sistem Akuntansi Penerimaan Kas Instalasi Rawat Inap pada Rumah Sakit Umum Daerah Kabupaten Sukoharj,Tugas Akhir, Surakarta

Romney, Marshall B., dan Paul John Steinbart. 2004. Accounting Information Systems : Sistem Informasi Akuntansi.Buku Satu. Edisi Sembilan. Jakarta: Salemba Empat 